\title{
CHARLES PERRAULT'S TALE AND ITS ENGLISH MODERNIST VARIANT. ANGELA CARTER AS REPRESENTATIVE OF MIDDLE- LITERATURE PHENOMENON
}

The article aims at identifying the specificity of Angela Carter's writings and their place in the world literary process. The writer's work is considered from the point of Chuprinin's theory of three main literature levels. Since the English short-story writer projects classic heritage on the instantaneous trends, it is being proved that according to this classification, the writer represents the phenomenon of "middle-literature". Hence, the acquisition and the usage of mythological elements take place. Consequently, the evolution of mythological images and motives of Charles Perrault's tale is discussed. The projection of myth on the writer's text and the archetypal and symbolic content of the tale are dwelled upon in the realm of magic realism. The emphasis is laid on the "Great Mother" archetype which stands as an important element of Angela Carter's modernist short story. The images of the old tale are analyzed from the point of Ferdinand de Saussure's theory. Thus, using Roland Barthes's mythopoeic scheme of analysis we treat and analyze myth as a sign.

It is this mergence of "the everlasting" classic tradition and the ephemeral that makes up the specificity of Angela Carter's creative method.

Key words: myth, archetype, sign, magic realism, middle-literature.

Дмитрієва В.В. Казка Шарля Перо та ії модерністський варіант. Анджела Картер, як представник феномена «мідл-літератури». Стаття дає уявлення про твори Анджели Картер і ї місце в світовому літературному процесі. Оповідання письменниці «Кривава кімната» розглядається з точки зору теорії Чуприніна С. про три основні рівні літератури. Наше дослідження ставить роботи Анджели Картер на один рівень з інтелектуальною прозою ії сучасників. Саме тому, у статmі використовується поняття «вічні теми», які фрункціонують у літературному просторі та набувають нових значень. Архетипічний та символічний зміст повісті висвітлюється в рамках такого напряму, як магічний реалізм. Образи старої казки аналізуються з точки зору теорії Фердинанда де Сосюра. Отже, заідно з міфотворчою схемою Ролана Барта ми розәлядаємо і аналізуємо міф як знак.

Ключові слова: міф, архетип, знак, магічний реалізм, мідл-література.

Дмитриева В.В. Сказка Шарля Перро и ее модернистский вариант. Анджела Картер, как представитель феномена «мидл-литературы». Данная статья освещает творчество Анджелы Картер и его место в мировом литературном пространстве. Рассказ писательницы «Кровавая комната» рассматривается с точки зрения теории Чупринина С. о трех основных уровнях литературы. Данное исследование ставит работы Анджелы Картер в один ряд с творчеством интеллектуальных писателей. Таким образом, в статье затрагивается понятие «вечных тем», которые существуют в литературном пространстве и обрастают новыми смыслами. Архетипы и символы повести «Кровавая комната» рассматриваются в рамках такого направления, как магический реализм. Используя теорию Ф. де Соссюра и мифопоэтическую схему его последователя Р. Барта, мы рассматриваем образы старой сказки, и сам мифф о Синей Бороде, как знак.

Ключевые слова: мифр, архетип, знак, магический реализм, мидл-литература.

Writing about the peculiarities of Angela Carter's creative method in "The Bloody chamber" we must first of all define her place in the world literary process. 
Identifying the specificity of Angela Carter's writings and their place in the world literary process, we consider her works from the point of Chuprinin's theory of three main literature levels.

Thirteen years ago, S. Chuprinin stated that "elite" and "popular" literature drew closer to each other at the beginning of the twenty first century and thus, he suggested three main literature types or rather classes: elite, middle and popular (12, 147-159). Middle-literature standing between these two extremes implied the amalgamation of both - intellectual and popular reading.

As is widely known, Angela Carter's works invoke feminist topics and are being widely read, especially by women all over the world. This wide popularity and readership provoked literary scholars to attribute A. Carter's short stories the place among popular literary heritage. Nevertheless, middle-literature as an actual phenomenon of modern literature uses classical myth motives but dwells upon widely understood, up to date questions, making this literature wellsold and attributing it a note of intellectuality in the same time (2, 28-34). Since Angela Carter's short story involves classic heritage we must by all means relate it to so called "middle-literature" class.

The twentieth century being not only the age of great discoveries, but also the time of reinterpretation and correction of the past, can subsequently be regarded as the period of active renovation of old and new myths. A variety of approaches to sustainable themes and plots prompted the researchers to look for fresh ways of deciphering renewed codes. This explains our attempt to explore the narrative codes of Angela Carter's mythopoetics.

Hence, to establish a comprehensive account of the problem outlined above we should address ourselves to the definition of longstanding common themes, motives and subjects that are presented in the works of A. Veselovsky. A gradual generalization of these topics took place resulting in their transformation into a generalized scheme $(3,71)$.

According to A. Veselovsky, the essential part of a mythopoetic research is the knowledge of "the old images" and understanding of their meaning, so it is natural, that analyzing the work of the researcher mentioned above, E. M. Meletinskii observes that many definitions proposed by a Russian scientist precede some conclusions made by C. G. Jung - the author of the archetypal theory $(17,40)$.

Thus, the ideas concerning collective unconscious and images-symbols found their development in the archetypal theory of Carl Gustav Jung. He proved that archetypal thinking is based on previously-formed instincts of phenomenon perception. Unconscious knowledge that is not based on any life logic is vividly expressed in the archetypal forms. In general, "the further we delve into the origins of a "collective image" (or, to express it in ecclesiastical language, of a dogma), the more we uncover a seemingly unending web of archetypal patterns that, before modern times, were never the object of conscious reflection" $(17,320)$.

This explains a generally accepted statement that in myth, history is preserved as a spiritual and intellectual heritage. It may be helpful to consider Tylor's statement that, "myth is the history of its authors, not of its subjects" (19, 376). 
The nineteenth century stands out as a period of "remythologization". Thus, the acquisition and usage of mythological elements in the culture of the time are brought to the forefront in literary analysis. At the early stages of their circulation, myths acquire different or additional meanings. These additional meanings appear due to a change in social sphere $(5,257,258)$.

In the twentieth century, this growing trend has prompted literary scholars to pay attention to the projection of myth, mythological images and motives on contemporary art. The attempt to decode "second-order myth" is particularly relevant nowadays, at the time of multiple creation of "retro-writings". As consequence, mythopoetics being a specific method of analysis opens a new stage of literary criticism $(4,84)$.

Mythopoetic methodology involves the study of archetypal and symbolic in literary writings, and in its basic components: in composition, plot and in its images (4, 84-86). Such analysis involves the detachment of mythopoetic model of world perception, which is realized by the author in the system of different poetic categories.

The archetypal plot about husband-killer that dates back to Bluebeard fairytale tradition, gaining relevance in contemporary literature, has formed in the process of refiguration of its cultural components such as the archetype of "the Wild Woman" and a "predator" (16).

The Wild Woman archetype has a quite long tradition of literary reflection. It has changed much at the beginning of the twentieth century, clearly reflecting changes in the social perception of the world. It is due to feminist sentiments, which the old view of the woman's mission became at variance with the apparent increase in women's activity in social matters.

In today's perception the image of Bluebeard, according to Clarissa Pinkola Estes, represents the archetype of a predator, which is designed to kill women's dreams and completely destroy her personal integrity. The predator symbolizes "a malevolent thing disguised as a benevolent thing" $(16,50-51)$.

If we stick to the Jungian representation of fairy-tale characters, we should have a close look at French modernists' works. Well-known writers Anatole France and Moris Maeterlinck dramatically changed the tyrant's character, replacing it with the image of an innocent person. Besides, M. Maeterlinck's Bluebeard character deserves not only sympathy, but also condemnation. Therefore, the exaggerated masculinity, inherent to a tyrant who Bluebeard appears to be in an early version of a fairy-tale, is being deconstructed. Hence, the constituents of the main opposition - "predator - victim" change places.

It's been a long time since Roland Barthes underlined the importance of the internal meanings, which are foregrounded when the message is read.

His research erases the predetermined character of the bounds, existing between the signifier and the signified, and thus, denies the permanence of an unambiguous interpretation of sign, even within the same language community (1). According Roland Barthes, language as a universal means of revealing meanings of signs does not imply its definite perception.

Circulating in society, the Sign acquires new additional ideological meanings. The same happens with myth (1). 
A. A. Potenbnya speaks about the correlation between word and myth which would further be underlined by Roland Barthes. Potebnya affirms that the construction of a new myth consists of a new word creation $(7,596)$.

Reconsidering Claude Lévi-Strauss' ideas on the relations between communicative and other social aspects, Roland Barthes dwelled upon modern myth structure that is focused on public conscience and speech practice, connected with it.

The "sign" that is considered the starting point in R. Barthes's works, is dwelled upon by the scientist in the aspect of inner meanings. Understanding of myth takes place in the process of deciphering and reading these signs. Referring to Ferdinand de Saussure's works, Barthes singles out the main elements of the sign system: the signifier and the signified. According to R. Barthes, myth proposes the same system of notion reflection $(1,616)$.

Using the mythopoetic scheme of analyses mentioned above, we consider it necessary to reveal the inner meanings of Angela Carter's work. Her story "The Bloody chamber", published in the eponymous collection in 1979, is of particular interest for mythopoetic studies and gender criticism.

Transforming the well-known fairy-tales, it reflects the specific features of creative thinking of the twentieth century authors. "The Bloody Chamber" story reinterprets a famous Charles Perrault fairy-tale "Bluebeard", using the achievements of modernist vision and as some researchers state, magic realism (13).

German researcher Franz Roh interprets the "miraculous" in modern literature as the reverse side of reality, not implying the presence of mystical or supernatural. "Miraculous" by changing the angle of view and with the help of life-likeness distortion acquires the meaning of "magic" $(18,15-31)$. In regard to English-myth writers, the "magic realism" is manifested in the creation of new myths and in wide usage of gothic and surrealistic features (13).

On the poetic level Angela Carter can be noted for a deep self-analysis of the main character, which determines the introduction of a detailed plot and brings about the effect of an emotional confession of the girl. Instead of the traditional chronological ordering the text offers a different outline of events the story begins with the rising action. Thus, the merits of the compositional structure of the short story are obvious. The usage of first-person narrative and the lack of exposition provide direct evidence that the text is aimed to excite the reader's interest. Compared with the narrative style of Charles Perrault, Angela Carter's text not only proposes a revisionist version of the old story, but gives a new version of the old plot which offers a realistic outline of events combined with symbolic content that constantly crops up throughout the text.

Getting ready for the wedding with Bluebeard, the young lady cast her thoughts back on the past. The mother's image holds a special place in the main character's mind:

"My eagle-featured, indomitable mother; what other student at the Conservatoire could boast that her mother had outfaced a junkful of Chinese pirates, nursed a village through a visitation of the plague, shot a man-eating tiger with her own hand and all before she was as old as l" (14). 
The very presence of the mother in the life of her daughter violates the rules of fairy-tale genre, because of the fact that the last one supposes the disappearance of both parents, especially the mother from her daughter's life before the plot starts to evolve. Moreover scientists are inclined to underline the importance of the heroine's rescue by her mother, which deviates from Charles Perrault's version when the heroine is saved by her brothers.

"The Bloody chamber" short story is piled up with implicative sighs, which is a constant feature of magic realism as a variation of symbolism. Being constantly repeated the signs have a subconscious influence on the receiver, creating the effect of suspense.

Building upon the work of anthropologists, we can assume that this phenomenon is always updated by the ancient archetypal understanding of the item that "firmly" settled in the memory as eternal a priori truths. Thus, in Angela Carter's short story the image of heroine's mother foretells trouble:

"There was a dress for her, too; black silk, with the dull, prismatic sheen of oil on water, finer than anything she'd worn since that adventurous girlhood in Indo-China, daughter of a rich tea planter" (14).

The black color which is perceived as negative in European cultural code is seen as funeral when we talk about clothes. Therefore, the mother is preparing for the wedding of her daughter, foreshadowing an imminent disaster. The descriptions of her mother's past follow each other one by one. Therefore, we face the story of the love that has hardened the heart of a middle-aged woman.

"For my mother herself had gladly, scandalously, defiantly beggared herself for love; and, one fine day, her gallant soldier never returned from the wars, leaving his wife and child a legacy of tears that never quite dried, a cigar box full of medals and the antique service revolver that my mother, grown magnificently eccentric in hardship, kept always in her reticule" (14).

From the earliest times, these maternal traits presented the archetypal image of the "Great Mother" C. G. Jung associated this archetype with such qualities as maternal care and compassion, "the magic authority of a woman over others", wisdom and spiritual elevation. The mother is the most important character, when there is a magical transformation and resurrection. The psychologist believes that this archetype can be foregrounded in a variety of situations:

"Its essence - the magic authority of the female; the wisdom and spiritual exaltation that transcend reason; any helpful instinct or impulse; all that is benign, all that cherishes and sustains, that fosters growth and fertility. The place of magic transformation and rebirth, together with the underworld and its inhabitants, are presided over by the mother" $(17,82)$. Начало фрормыКонец фрормы

The scene of coition holds a specific place in Angela Carter's story. For centuries the first act of intimacy meant a turning point for a woman symbolizing transition from her ordinary life in the father's house to a new life, where she would face the unknown.

Hence, the writer conveys the psychology of the couple in detail and provides the turning point of her new life with a sacred meaning. Invoking the rite of passage, mentioned by V. Ja. Propp in the "Morphology of fairy-tale" we 
come to the thought that here the person receives secret knowledge (8).

The image of mirrors stands alongside with the symbols mentioned above. Angela Carter's character sees herself the way her husband perceives her - as a victim. Furthermore, the mirror unmasks his real nature $(10,210)$.

A large number of mirrors surrounding the marital bed contributes to hyperbolization of action.

Besides the aroma of white lilies, being integrated into the plot as an implying detail increases the tension in the narrative, which adds up to a pejorative emotional effect. White lilies in mythological sense are widely considered in two main forms. They symbolize death as well as purity $(10,292)$.

Still, the saturation of the old plot with the old images and characters must not be considered the main merit of Angela Carter's fairy-tale version. Using the symbol of the forest, which is, according to V. Propp, associated with the rite of initiation and transition into the realm of the dead, Angela Carter reinterprets it, placing her murderer in the castle on water. The author does not specify how and on what it is constructed, but the text shows that you can get to this place only at low tide.

"And, ah! his castle. The faery solitude of the place; with its turrets of misty blue, its courtyard, its spiked gate, his castle that lay on the very bosom of the sea with seabirds mewing about its attics, the casements opening on to the green and purple, evanescent departures of the ocean, cut off by the tide from land for half a day ... that castle, at home neither on the land nor on the water, a mysterious, amphibious place, contravening the materiality of both earth and the waves" (14).

Consequently, as in the original versions of the tale, Bluebeard's possessions are in the realm of the dead. Hence, we can assume that in this case, Angela Carter resorts to the Charon myth, showing how Bluebeard moves through water to his castle, which is located on the island and is cut off from the rest of the world. It brings to mind Arnold Böcklin's famous painting "Isle of the Dead".

The most obvious alteration from the classic story presented by Charles Perrault is the final scene in which the mother miraculously saves her daughter from certain death.

The role previously played by the heroine's brothers, shifts to the "female parent". Thus, the archetype of "the Great Mother" warrior and protector is actualized.

Summarizing, we can assume that Angela Carter skillfully makes use of the classic story, but interprets it within the scope of modernism, and magical realism in particular. This allows us to bring Carter into line with intellectual writers, providing a wide readership with writings worth reading and therefore, enriching old plots with new up-to-date connotations.

\section{Bibliography}

1. Барт Р. Избранные работы: Семиотика: Поэтика: пер. с фрр. / Сост., общ. и вступ. ст. Г. К. Косикова. М.: Прогресс, 1989. - 615 с.

2. Валуева Н. Н. "Миддл-литература" как составляющая современного литературного процесса [Електронний ресурс] / Н. Н. Валуева // Наукові записки Харківського національного педагогічного університету ім. Г. С. Сковороди. Сер.: Літературознавство. - 2012. - Вип. 
1(1). - С. 28-34. - Режим доступу: http://nbuv.gov.ua/UJRN/NzI_2012_1(1)_6

3. Веселовский А. Н. Историческая поэтика. - М.: Высшая школа, 1989. - 406 с.

4. Калиниченко Л. А. Мифопоэтика произведений Прилепина (на примере романов "Черная обезьяна" и "Патологии") // Филологические науки. Вопросы теории и практики. - Тюмень, 2015. [Электронный ресурс]: http://cyberleninka.ru/article/n/mifopoetikaproizvedeniy-z-prilepina-na-primere-romanov-chernaya-obezyana-i-patologii.

5. Леви-Брюль Л. Сверхъестественное в первобытном мышлении. М.: Педагогика-пресс, 1994. - 608 c.

6. Мелетинский Е. М. “Историческая поэтика” А. Н. Веселовского и проблемы происхождения повествовательной литературы // Историческая поэтика: Итоги и перспективы изучения. М., 1986. - С. 25-52.

7. Потебня А. А. Слово и мифр. М.: Правда, 1989. - 624 с.

8. Пропп В. Я. Морфология волшебной сказки. М.: Лабиринт, 2001. - 192 с.

9. Ткаченко А. О. Мистецтво слова: Вступ до літературознавства. Київ: ВПЦ "Київський університет”, 2003. - 448 с.

10. Тресиддер Д. Словарь символов. / Д. Тресиддер. - М: ФАИР-ПРЕСС, 2001. - 448 с.

11. Хализев В. Е. Теория литературы. М.: Академия, 2009. - 438 с.

12. Чупринин С. Звоном щита [Електронний ресурс] / Сергей Чупринин // Знамя. - 2004. Режим доступу до ресурсу: http://magazines.russ.ru/znamia/2004/11/chu13.html.

13. Шамсутдинова Н. 3. Магический реализм в современной британской литературе: Анжела Картер, Салман Рушди - Москва, 2008. [Электронный ресурс]: http://www.dissercat. com/content/magicheskii-realizm-v-sovremennoi-britanskoi-literature-anzhela-kartersalman-rushdi

14. Carter A. The Bloody Chamber and Other Stories [Електронний ресурс] / Carter // Vintage. - 1995. - Режим доступу до ресурсу: http://www.angelfire.com/falcon/rote/CARTER.htm.

15. Cirlot J. E. A Dictionary of Symbols / J. E. Cirlot. - London, 1971. - (Second edition). - 451p.

16. Estés C. P. Women Who Run with the Wolves [Електронний ресурс] / C. P. Estés // Ballantine Books. - 1996. - Режим доступу до ресурсу: http://www.twirpx.com/file/1652469/.

17. Jung C. G. The archetypes and the collective unconscious. / C. G. Jung. - Princeton: Princeton University Press., 1981. - 451p.

18. Roh F. Magic Realism. Post-Expressionism. Magic Realism: Theory, Practice, Community. / F. Roh. - Durham, NC and London: Duke University Press, 1995. - 592p.

19. Tylor E. B. Primitive culture: researches into the development of mythology, philosophy, religion, language, art, and custom. / E. B. Tylor. - download: Cambridge University Press, 2010. $-528 p$.

\section{References}

1. Bart R. (1989). Izbrannyie rabotyi: Semiotika: Poetika [Selected writings: Semiotics. Poetics.] Moskva: Progress.

2. Valueva N. N. (2012). "Middl-literatura" kak sostavlyayuschaya sovremennogo literaturnogo protsessa [Middle-literature as a part of modern literary process]. Naukovizapiski Harkivskogo natsionalnogo pedagogichnogo universitetu im. G. S. Skovorodi. Vol. 1(1), 28-34. Retrieved from http://nbuv.gov.ua/UJRN/Nzl_2012_1(1)_6.

3. Veselovskiy A. N. (1989). Istoricheskaya poetika [From the Introduction to Historical Poetics: Questions and Answers] - Moskva: Vyisshaya shkola.

4. Kalinichenko L. A. (2015). Mifopoetika proizvedeniy Z. Prilepina (na primere romanov "Chernaya obezyana" $i$ "Patologii") [Prilepins mythopoetics (based on novels "The Black Monkey" and "Pathologies"]. Filologicheskie nauki. Voprosyi teorii I praktiki. Retrieved from http://cyberleninka.ru/article/n/mifopoetika-proizvedeniy-z-prilepina-na-primere-romanovchernaya-obezyana-i-patologii.

5. Levi-Bryul L. (1994). Sverh'estestvennoe $v$ pervobyitnom myishlenii [Primitives and the Supernatural] Moskva: Pedagogika-press.

6. Meletinskiy E. M. (1986). Istoricheskaya poetika A. N. Veselovskogo i problemyi proishozhdeniya povestvovatelnoy literaturyi [Historical poetics of Alexander Veselovsky and the problems of prose origin]. Istoricheskaya poetika: Itogi i perspektivyi izucheniya, 25-52. Moskva. 
7. Potebnja A. A. (1989). Slovo i mif [Word and myth] Moskva: Pravda.

8. Propp V. Ya. (2001). Morfologiya volshebnoy skazki [Morphology of the Folktale] Moskva: Labirint.

9. Tkachenko A. O. (2003).My`stecztvo slova: Vstup do literaturoznavstva [The art of writing: Introduction to literary criticism]. Ky`yiv: VPCz "Ky`yivs`ky j universy tet".

10. Tresidder D. (2001). Slovar simvolov [The Complete Dictionary of Symbols]. Moskva: FAIRPRESS.

11. Halizev V. E. (2009). Teoriya literaturyi [Theory of literature] Moskva: Akademiya.

12. Chuprinin S. (2004). Zvonom schita [By the clatter of the chield]. Znamya, No 11, 147,159. Retrieved from http://magazines.russ.ru/znamia/2004/11/chu13.html.

13. Shamsutdinova N. Z. (2008). Magicheskiy realizm v sovremennoy britanskoy literature: Anzhela Karter, Salman Rushdi [Magic realism in modern British literature: Angela Carter, Salman Rushdi] Moskva.

14. Carter A. (1995). The Bloody Chamber and Other Stories. Vintage. doi: http://www.angelfire. com/falcon/rote/CARTER.htm.

15. Cirlot J. E. (1971). A Dictionary of Symbols. Second eddition. London: Routladge.

16. Estés C. P. (1996). Women Who Run with the Wolves. New York: Ballantine Books. doi: http:// www.twirpx.com/file/1652469/.

17. Jung C. G. (1981). The archetypes and the collective unconscious. Princeton: Princeton University Press.

18. Roh F. (1995). Magic Realism. Post-Expressionism. Magic Realism: Theory, Practice, Community. Durham, NC and London: Duke University Press.

19. Tylor E. B. (2010). Primitive culture: researches into the development of mythology, philosophy, religion, language, art, and custom. Cambridge: Cambridge University Press.

Стаття надійшла до редакції 20.01.2017 p. 